\title{
Revisiting global health from the periphery: the Zika virus
}

\author{
Revisitando a saúde global a partir da periferia: o vírus Zika
}

\author{
Jose Ragas \\ Professor, Instituto de Historia/Pontificia Universidad Católica de Chile. \\ Macul - Santiago - Chile \\ jose.ragas@uc.cl
}

ZIKA

FRUM THE

BRAZILIAN BACKLANDS

DEBORA DINIZ

DINIZ, Debora. Zika: from the Brazilian backlands to global threat. Translated by Diane Grosklaus Whitty. London: Zed Books. 2017. 156p.
TO GLOBAL THREAT

Bioethics professor Debora Diniz of the University of Brasilia has written a beautiful as well as compelling account of the tragic months between the first alerts of the Zika virus and the official efforts by the Brazilian government and the scientific community to contain the virus in the country while preventing its expansion worldwide. What may have been expected to be a clean account of how the virus was discovered and finally quashed instead is a dramatic narrative of the complex, tense, and at times contradictory actions and decisions taken to fight an enemy with a none-too-clear identity. The original version of the book, Zika: do sertão nordestino à ameaça global, was accompanied by an award-winning documentary which is now available on YouTube. Diniz is also the co-founder of Anis: Institute of Bioethics, which focuses on the intersection of bioethics and human rights in Latin America.

The text goes beyond a simple chronicle of Zika's spread, and maintains an impressively personal touch while describing the technical and scientific procedures. One of its main goals is to introduce a clear narrative of the problem as well as the intricate and simultaneous paths adopted by physicians and scientists until the virus was confirmed to be Zika. Unlike other narratives of epidemics, where the focus centers on how the disease was contained and describes an active, organized team effort, the picture that emerges from this episode is a rich yet somber scenario of actors, policies, and non-human agents. The ethnographic perspective pays off, allowing readers to follow mothers mourning their newborns, bitter disputes among scientists, and the way in which government offices deliberately ignored contributions from the Brazilian northeast. Zika and its carrier become an excuse to dissect how science is produced, contested, and legitimized as the result of myriad regional, gender, and professional tensions. At the same time, science is elegantly disassembled into its basic units to restore the humanity behind it.

Diniz has done a remarkable job explaining the complex genealogy of the virus in lay terms, from its isolation in Uganda in 1947 until its last known outbreak in French Polynesia. 
Rather than following a single pattern, the book examines the multiple hypotheses regarding the disease's arrival in Brazil, ultimately focusing on the FIFA Confederations Cup. It also highlighted the significance of confirming that the virus is transmitted congenitally from mother to fetus, causing microcephaly and even death in newborns. The author specifically highlights the decisive role played by the women stricken by Zika during their pregnancies as they provided data to doctors and scientists or even made wrenching decisions such as donating the bodies of their babies for research.

The book is a very good example of the need to explore how science is produced within a particular setting, the tensions that arise in the process, and how it is disseminated within the country and around the world. As the author reflects in the opening pages: "There was a Brazilian, or perhaps Northeastern, touch to how science was done during these discoveries of Zika and its vertical transmission" (Diniz, 2017, p.3). Discerning this "Brazilian touch" then transforms into an open inquiry throughout the book as we learn how science and religious beliefs coexist with each other, and how "human warmth and solidarity" emerged among those exposed to the virus. Given the rapid spread of the Zika virus and the scarcity of knowledge about the disease in the country, Brazilian policy makers, scientists, and physicians had to monitor its development under extraordinary circumstances, along with pressure from both national authorities and the international community. It is reasonable to conclude that the recent crisis generated by the Zika virus changed how science is produced in Brazil and the way its practitioners engage with the global scientific community. In stressing the national and regional distinctiveness of Brazilian science, the book invites us to rethink certain paradigms such as the periphery/ global tension. It also suggests why periphery should no longer be necessarily (and exclusively) associated with material precariousness, but rather perhaps with alternative forms and methods to practice the same discipline in various settings.

The translation deserves special recognition for several reasons. The book was initially published in Portuguese but rapidly translated into English, which should be a more frequent occurrence. Even so, such a contribution to the field is certainly a good sign for further translations and for bringing sorely-needed diversity to the hegemony of cases in the North Atlantic (or even in the Global South but described by scholars from the North). The book not only adds an important case but presents a unique style and perspective, showcasing how science is produced in a different setting. The narrative presentation and first-hand account allow the book to reach a broader audience (in both Portuguese and English), which is not always easy for scientific texts. The presence of a Portuguese-to-English translator specialized in health and social sciences who is sensitive to the content has been a major asset, given her delicate task of explaining the Brazilian context to foreign readers. The book can also work very well with students at different levels; I assigned the book to my seminar and it was very well received.

I do recommend the book enthusiastically, not only to those in the field of history of medicine and health but also to readers outside these areas. Zika: from the Brazilian backlands to global threat revisits this episode from a new angle, bringing together less familiar actors, new methods of research, and lessons to understand and hopefully combat future epidemics. 


\section{REFERENCE}

DINIZ, Debora.

Zika: from the Brazilian backlands to global threat. London: Zed Books. 2017.

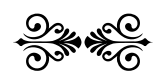

